Chirurgia (2017) 112: 143-151

No. 2, March - April

Copyright@ Celsius

\title{
Cholecystolithotomy Combined Armillarisin A versus Cholecystectomy in Cirrhotic Portal Hypertension Patients with Symptomatic Cholelithiasis
}

\author{
Yang Fei', Wei-qin Li', Guang-quan Zong' ${ }^{2}$, Jian Chen², Wei Wang ${ }^{2}$ \\ 'Surgical Intensive Care Unit (SICU), Department of General Surgery, Jinling Hospital, Medical School of Nanjing University, \\ Nanjing, China \\ ${ }^{2}$ Department of General Surgery, The 81st Hospital of PLA, PLA Liver Disease Center, Nanjing, China
}

Corresponding author:

Yang Fei, MD

Surgical Intensive Care Unit (SICU),

Department of General Surgery,

Jinling Hospital, Medical School of

Nanjing University, Nanjing, China

E-mail: fei_yanggood@163.com

Received: 31.01 .2017

Accepted: 8.03.2017

\section{Rezumat}

Colecistotomia combinată cu Armillarisin A versus colecistectomia la pacienții cu ciroză și hipertensiune portală cu colelitiază simptomatică

Scop: De a evalua în spitalul autorilor dacă la pacienții cu ciroză şi hipertensiune portală cu colelitiază simptomatică tratamentul prin colecistotomie combinată cu Armillarisin A ar aduce noi beneficii. Metode: Şaizeci şi unu de pacienți cu ciroză şi hipertensiune portală cu boală litiazică veziculară simptomatică tratați pentru colelitiază fie prin colecistotomie combinată cu Armillarisin A (grupul A), fie prin colecistectomie (grupul B), în perioada februarie 2007 martie 2011, au fost analizați retrospectiv. Aceşti pacienți erau concomitent tratați pentru varice esofagice. Au fost analizate datele operatorii relevante, modificările apărute la nivelul analizelor de sânge, complicațiile postoperatorii şi simptomatologia.

Rezultate: $\mathrm{Nu}$ au existat diferențe semnificative între grupul A şi grupul B în ceea ce priveşte durata operației, pierderea intraoperatorie de sânge, timpul până la reluarea dietei postoperator şi durata spitalizării $(\mathrm{P}>0.05)$. Profilul biochimic al funcției hepatice şi scorul Child-Pugh la 2 săptămâni şi o lună după operație au fost ambele semnificativ mai mici în grupul A comparativ cu grupul B (ALT, 0.008, 0.011; AST, 0.006, 0.003; scorul Child-Pugh, 0.010, respectiv 0.016). Totuşi, la 6 luni postoperator, modificările nu au fost semnificative statistic $(\mathrm{P}>0.05)$. Cu excepția recurenței litiazei biliare şi a infecțiilor de plagă, incidentele sau complicațiile postoperatorii incluzând fistule biliare, insuficiență hepatică şi infecția subfrenică au prezentat diferențe semnificative între cele două 
grupuri $(\mathrm{P}=0.037, \mathrm{P}=0.041$, respectiv $\mathrm{P}=0.019)$. După o urmărire medie de $4,2 \mathrm{ani}$, supraviețirea pacienților a fost de $100 \%$. Douăzeci şi şapte de pacienți din grupul A (93\%) nu mai prezintă nici un simptom biliar.

Concluzii: Colecistotomia combinată cu Armillarisin A este un tratament util în litiaza veziculară simptomatică la pacienții cu ciroză şi hipertensiune portală ce prezintă un risc crescut pentru colecistectomie. Aceasta prezervă funcția veziculară şi reduce riscul de insuficiență hepatică. În plus, rata de recurență a litiazei este relativ scăzută.

Cuvinte cheie: colecistotomie, colecistectomie, hipertensiune portală, recurență, litiază

\begin{abstract}
Object: To discover whether cirrhotic portal hypertension patients with symptomatic cholelithiasis would benefit from cholecystolithotomy combined with Armillarisin A in the authors' hospital.

Methods: Sixty-one patients with cirrhotic portal hypertension and symptomatic gallstone disease who underwent either cholecystolithotomy combined with Armillarisin A (group A) or cholecystectomy (group B) for cholelithiasis from Feb 2007 to March 2011 were retrospectively reviewed. These patients were undergoing simultaneous procedure for esophageal varices. The operation-relevant information, change of laboratory examination data, postoperative complications and symptoms were analyzed. Results: There were no significant differences between group A and group B in mean operative time, intraoperative blood loss, time to resume diet postoperatively and length of hospital stay $(\mathrm{P}>0.05)$. The hepatic function biochemical profile and Child-Pugh's score at 2 weeks and 1 month after operations were both altered significantly less in group A than in group B (ALT, 0.008, 0.011; AST, 0.006, 0.003; Child-Pugh's score, 0.010, 0.016, respectively). However, at 6 months postoperatively, the changes were not significant $(\mathrm{P}>0.05)$. Except for gallstone recurrence and wound infection, occurrences or development of postoperative complications including biliary fistula, liver failure and subphrenic infection showed significant differences between the two groups $(\mathrm{P}=0.037, \mathrm{P}=0.041, \mathrm{P}$ $=0.019$, respectively). After a mean follow-up of 4.2 years, all patients remain alive. Twenty-seven patients in group A (93\%) are free of biliary symptoms.

Conclusion: Cholecystolithotomy combined with using Armillarisin A is a useful treatment for symptomatic gallstones in patients with cirrhotic portal hypertension who are at high risk for cholecystectomy. It preserves gallbladder function and reduces the possibility of liver failure; moreover the rate of recurrent gallstones are relatively low.
\end{abstract}

Key words: cholecystolithotomy, cholecystectomy, portal hypertension, recurrence, gallstone

\section{Instruction}

The incidence of cholelithiasis in patients with cirrhotic portal hypertension (PHT) is two-fold higher when compared to that of the noncirrhotic population (1). This is due to intravascular hemolysis, hypersplenism, increased estrogen levels and decreased gallbladder motility and emptying. Cholecystectomy is the most common treatment for gallstones (2).
However, in patients with cirrhotic PHT it is associated with a high rate of morbimortality related to excessive blood loss, postoperative liver failure and sepsis (3). Furthermore, the gallbladder is an organ with precise functions of concentrating and storing bile and regulating bile flow. In order to decrease the risk from cholecystectomy and preserve the function of the gallbladder in these patients, cholecystolithotomy combined with Armillarisin A 
(3-acetyl-5-hydroxymethyl-7-hydroxycoumarin) has been performed in our department to treat cholelithiasis. The objective of the present study is to discover whether cirrhotic PHT patients with symptomatic cholelithiasis would benefit from this technique.

\section{Methods}

\section{General information}

We undertook a retrospective medical record review of 29 patients with cirrhosis PHT caused by hepatitis B and symptomatic gallstone disease. They had all undergone a selective double disconnection (SDPDPV) combined cholecystolithotomy procedure and were treated with Armillarisin A (group A) as treatment for variceal hemorrhage and cholelithiasis at The 81st hospital of PLA from Feb 2007 to March 2011. All operations were performed by the same surgical team (Zong et al.). During this same time interval, 32 patients received a SDPDPV combined cholecystectomy (group B) for management of variceal bleeding and cholelithiasis.

The diagnoses of these patients were all confirmed by endoscopy and Doppler ultrasonography. Our indications for surgery included, 1) the episodes of gastroesophageal variceal hemorrhage, within a 1-month interval between the last attack and date of surgical procedure, which could not be controlled by medical means and endoscopic therapy, and 2) a symptomatic history of cholecystitis which had been confirmed by Doppler ultrasound.

All of the patients had no associated serious cardiopulmonary diseaseor history of obstructive jaundice. The patients with Child-Pugh's score grade $\mathrm{C}$ were excluded. The characteristics of the two surgical groups including age, gender, Child-Pugh's score and preoperative biochemical tests are summarized in Table 1. Biochemical tests were examined within 1 to 3 days preoperatively.

\section{Operative technique}

The SDPDPV procedure was described by Zong et al (4). It was performed through an expanded left subcostal incision. In the SDPDPV, the free portal pressure (FPP) was measured by inserting a catheter into the portal trunk through a branch of the right gastroepiploic vein. After conventional extreme splenectomy, the FPP was remeasured. The proximal stomach was then devascularized close to the gastric wall just above the crow's foot along the lesser curvature from the incisura angularis up to the esophagus. By dissecting the anterior serosal layer and the left lateral peritoneum covering the esophagus, and separating the muscle layers carefully, the paraesophageal vein was exposed. When the left gastric artery and left gastric vein were exposed, the gastric branch of left gastric vein and branches of left gastric artery were disconnected and suture-ligated close to the gastric wall of the lesser curvature in order to preserve the trunk of the left gastric vein and artery. Then, perforating branches from the paraesophageal vein to the lower part of the esophagus were disconnected and sutureligated, trying to preserve the paraesophageal vein in its entirety. Dissection of the lower part of the esophagus was performed up to 7 to 10 $\mathrm{cm}$ above the cardia. Whole-layer discontinuous suturing guided by a stomach tube with $3-0$ prolene threads was performed around the lower part of esophagus at the area 2 to $-10 \mathrm{~cm}$ above the cardia. The seromuscular layers of the lesser curvature were closed with interrupted silk sutures. After SDPDPV, the fundus of the gallbladder was sewn with $4 \#$ sutures so that the gallbladder and liver margin could be lifted to achieve satisfactory exposure and visualization of the gallbladder. Thereafter, an incision was made in the fundus of gallbladder, the cystic duct was clamped using the operator's left hand to prevent gallstones from falling into the common bile duct, and gallstones were extracted with oval forceps. After the larger stones had been removed, a silicone catheter was inserted into the incision of the gallbladder fundus to rinse off the inner wall of the gallbladder with normal saline. This flushing procedure was continued until no muddy stones or biliary sludge could be seen in 
the flush fluid. At this time complete gallstone clearance was confirmed. When the operator's left hand was released from the cystic duct, yellow bile could immediately be seen flowing out . After the incision in the fundus of the gallbladder had been disinfected thoroughly, the whole incised layer of the gallbladder was sutured discontinuously with 3-0 Vicryl threads. Two peritoneal cavity drainage tubes were placed at the left subphrenic location and foramen of Winslow respectively. Finally, the FPP was remeasured.

In group B, after SDPDPV, Calot's triangle were dissected, After cutting and ligation of the cystic duct, the gallbladder was stripped from the gallbladder bed.

In group $\mathrm{A}$, patients were routinely treated with intravenous Armillarisin A $(10 \mathrm{mg}$, four times daily) perioperatively, and then with Armillarisin A tablets (10 mg, thrice daily) for at least 1 year after being discharged from our hospital. After discharge, the patients were asked to comply in strict accordance with the medication instructions, and the importance of the timing of their Armillarisin A doses were emphasized.

\section{Follow-up studies}

All subjects gave written informed consent to participate in the follow-up study. The mean length of follow-up was $4.2 \pm 0.9$ years (range 37 to 74 months). Follow-up investigations consisting of abdominal ultrasonography and clinical assessment were conducted at 6-month intervals for first year after surgical treatment and on a yearly basis thereafter. Clinical variables including episodes of recurrent gallstones, infection, biliary fistula, and so on were examined postoperatively. Laboratory variables, including biochemical tests, were systematically examined at 2 weeks, 1 month and 6 months postoperatively.

In our studies, liver failure was defined as prothrombin activity (prothrombin time) $\leq 20 \%$, or the occurrence of the hepatorenal syndrome, or the development of grade III to IV hepatic encephalopathy based on cirrhosis. Operative mortality was defined as death within 30 days of surgery (5). The recurrence of gallstones was defined as the ultrasonographic detection of any echogenic object in the gallbladder with acoustic shadow or gravity dependence (sludge).

The research protocol was approved by the ethics committees of our hospital, and all the participants gave written informed consent.

\section{Statistical analysis}

All statistical analyses were performed using SPSS 15.0 software (SPSS, Chicago, IL, USA). Continuous data were expressed as mean values \pm standard deviation (SD). Significant differences between groups were determined by chi-squared analysis and unpaired Student's t- test. P-values $<0.05$ were considered statistically significant.

\section{Results}

\section{Preoperative comparison of the two operational groups}

There were no significant difference between the group A and the group B of the preoperative database including age, gender, follow-up time, Child-Pugh's score, platelet count, hepatic function tests and number of stones $(\mathrm{P}>0.05)$ (Table 1). The two groups were well balanced in the distribution of prognostic factors and other characteristics.

\section{Operation-relevant information}

All 61 operations were successful. None of the patients died in the postoperative course within 30 days, and no patients were readmitted within 30 days of surgery.

The mean operative time of group A was $257.1 \pm 64.2$ minutes with a range of 145 to 266 minutes. In group B, it was $248.3 \pm 69.0$ minutes with a range of 132 to 267 minutes. The difference in mean operative time between the two groups was not significant $(\mathrm{P}=0.451)($ Table 2).

The intraoperative blood loss of group A was $526.3 \pm 71.6 \mathrm{ml}$; in group B, it was $638.5 \pm$ 
Table 1. Preoperative clinical characteristics of the patients

\begin{tabular}{|c|c|c|c|c|}
\hline & Group $A(n=29)$ & Group B $(n=32)$ & $t / \chi^{2}$-value & $P$-value \\
\hline Age (mean \pm SD; years) & $48.3 \pm 8.4$ & $44.8 \pm 7.5$ & 0.821 & 0.115 \\
\hline \multicolumn{5}{|l|}{ Gender } \\
\hline Male & 15 & 20 & 0.566 & 0.317 \\
\hline Female & 14 & 12 & & \\
\hline Child-Pugh's score & $6.8 \pm 1.3$ & $7.1 \pm 1.2$ & 0.163 & 0.692 \\
\hline Follow-up time (years) & $4.4 \pm 1.5$ & $3.9 \pm 1.7$ & 0.865 & 0.091 \\
\hline Platelets (/L) & $28.7 \times 109$ & $24.2 \times 109$ & 0.367 & 0.542 \\
\hline $\mathrm{ALT}(\mathrm{IU} / \mathrm{L})$ & $26.3 \pm 7.2$ & $27.1 \pm 6.9$ & 0.223 & 0.514 \\
\hline AST $(I U / L)$ & $27.2 \pm 7.0$ & $27.8 \pm 6.3$ & 0.178 & 0.691 \\
\hline \multicolumn{5}{|l|}{ Stone number } \\
\hline Solitary & 7 & 12 & 0.704 & 0.229 \\
\hline Multiple & 22 & 20 & & \\
\hline
\end{tabular}

Abbreviations: ALT, alanine aminotransferase; AST, aspartate aminotransferase

$97.3 \mathrm{ml}$. The difference in blood loss between the two groups was also not significant $(\mathrm{P}=$ 0.183) (Table 2).

In the study, we found that there was no significant difference in the time taken for resumption of normal diet between patients in group $\mathrm{A}$ (4.6 \pm 0.8 days) and those in group $\mathrm{B}$ (5.1 \pm 1.3 days $)(\mathrm{P}=0.291)$, as recorded in Table 2.

With respect to length of hospital stay, the patients in group A were not discharged from hospital significantly earlier than those in group $\mathrm{B}(\mathrm{P}=0.502)$ (Table 2$)$.

\section{Laboratory examination and hepatic functional reserve}

The biochemical profile tests of hepatocyte function such as alanine aminotransferase (ALT) and aspartate aminotransferase (AST) at 2 weeks and 1 month postoperatively were both significantly less altered in group A than in group $\mathrm{B}(\mathrm{P}<0.05)$. However, at 6 months postoperatively, the changes were not significant between the two groups $(\mathrm{P}>0.05)$ (Table 3).

Child-Pugh's classification is a well-validated method of assessing hepatic functional reserve in cirrhosis (6). In our studies, at 2 weeks and 1 month postoperatively, Child-Pugh's scores of group A were significantly lower than that of group $\mathrm{B}$ significantly $(\mathrm{P}<0.05)$ for both timepoints. However, the differences in Child-Pugh's score were not significant at 6 months postoperatively between the 2 groups $(\mathrm{P}>0.05)$ (Table 3).

\section{Postoperative complications}

\section{Gallstone recurrence}

Recurrent gallstones in group A showed an incidence of $2 / 29(6.9 \%)$, but there was no recurrence of gallstones in group B because of

Table 2. Operation-relevant information

\begin{tabular}{lcccc}
\hline & Group A $(\mathbf{n}=\mathbf{2 9})$ & Group B $(\mathbf{n}=\mathbf{3 2})$ & $\boldsymbol{t}$-value & $\boldsymbol{P}$-value \\
\hline Operative time (mins) & $257.1 \pm 64.2$ & $248.3 \pm 69.0$ & 0.283 & 0.451 \\
\hline Intraoperative blood loss (ml) & $526.3 \pm 71.6$ & $638.5 \pm 97.3$ & 0.706 & 0.183 \\
\hline Time to resumption of diet (days) & $4.6 \pm 0.8$ & $5.1 \pm 1.3$ & 0.532 & 0.291 \\
\hline Length of hospital day (days) & $24.2 \pm 7.8$ & $23.6 \pm 8.2$ & 0.217 & 0.502 \\
\hline
\end{tabular}


Table 3. Postoperative biochemical definitions of cirrhotic patients

\begin{tabular}{|c|c|c|c|c|c|c|c|}
\hline & \multicolumn{2}{|c|}{ Group $A(n=29)$} & \multicolumn{4}{|c|}{ Group B $(n=32)$} & P-value \\
\hline ALT (IU/L) & $26.8 \pm 4.9$ & $25.6 \pm 5.8$ & $28.9 \pm 6.3$ & $31.1 \pm 7.0$ & $29.6 \pm 6.4$ & $30.2 \pm 6.8$ & $\begin{array}{l}{ }^{\mathrm{a}} 0.008 \\
{ }^{\mathrm{b}} 0.011 \\
{ }^{\mathrm{c}} 0.263\end{array}$ \\
\hline AST (IU/L) & $27.4 \pm 6.2$ & $24.5 \pm 6.0$ & $30.4 \pm 5.6$ & $33.8 \pm 6.7$ & $30.7 \pm 7.3$ & $31.3 \pm 6.6$ & $\begin{array}{l}{ }^{\mathrm{a}} 0.006 \\
{ }^{\mathrm{b}} 0.003 \\
{ }^{\circ} 0.378\end{array}$ \\
\hline Child-Pugh's score & $6.0 \pm 1.4$ & $5.7 \pm 1.9$ & $6.3 \pm 1.7$ & $7.2 \pm 1.9$ & $6.7 \pm 1.6$ & $6.6 \pm 1.6$ & $\begin{array}{l}{ }^{\mathrm{a}} 0.010 \\
{ }^{\mathrm{b}} 0.016 \\
{ }^{\circ} 0.192\end{array}$ \\
\hline
\end{tabular}

${ }^{a}$ comparison of the 2 groups 2 weeks after operation.

${ }^{\mathrm{b}}$ comparison of the 2 groups 1 month after operation.

'Comparison of the 2 groups 6 months after operation.

ALT, alanine aminotransferase; AST, aspartate aminotransferase.

cholecystectomy having been performed. The differences in incidence of recurrent gallstones in the 2 groups were not significant $(\mathrm{P}=0.082)$ (Table 4).

\section{Biliary fistula}

The incidence of postoperative biliary fistula was much lower after group A $(3.4 \%, 1 / 29)$ compared to group B $(15.6 \%, 5 / 32)(\mathrm{P}=0.037)$ (Table 4).

\section{Liver failure}

Liver failure did not occur in group A; nevertheless it occurred in 3 patients $(9.4 \%)$ in group B $(\mathrm{P}=0.046)$ (Table 4).

\section{Subphrenic infection and wound infection}

Subphrenic infection in group A and group B showed had an incidence of 1/29 (3.4\%) and
$6 / 32(11.2 \%)$ respectively $(\mathrm{P}=0.019)$. However, with respect to wound infection, the difference between the two groups (13.8 versu. 18.8\%) was not significant $(\mathrm{P}=0.291)($ Table 4$)$.

\section{Follow-up}

After a mean follow-up of 4.2 years, all patients remain alive. Twenty-seven patients in group $\mathrm{A}$ are free of biliary symptoms; 2 other patients (7\%) suffer from non-specific gastrointestinal tract dyspepsia and mild right hypochondrial pain. In group B, 4 patients (12.5\%) developed dyspepsia. The difference between groups was not significant $(\mathrm{P}=0.151)$.

\section{Discussion}

Patients with cirrhosis are at increased risk of developing gallstone disease compared with the noncirrhotic population. The prevalence of cholelithiasis in cirrhosis can be up to $29 \%$ (7).

Table 4. Postoperative complications of the two groups

\begin{tabular}{lcccc}
\hline & Group A $(\mathbf{n}=\mathbf{2 9})$ & Group B $(\mathbf{n}=\mathbf{3 2})$ & $\boldsymbol{\chi}^{2}$-value & $\boldsymbol{P}$-value \\
\hline Recurrent gallstones & $2(6.9 \%)$ & $0(0 \%)$ & - & $0.082^{\mathrm{a}}$ \\
\hline Biliary fistula & $1(3.4 \%)$ & $5(15.6 \%)$ & 2.965 & 0.037 \\
\hline Liver failure & $0(0 \%)$ & $3(9.4 \%)$ & - & $0.046^{\mathrm{a}}$ \\
\hline Subphrenic infection & $1(3.4 \%)$ & $6(18.8 \%)$ & 3.864 & 0.019 \\
\hline Wound infection & $4(13.8 \%)$ & $6(18.8 \%)$ & 0.675 & 0.291 \\
\hline
\end{tabular}

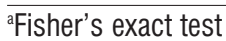


Reduction in gallbladder emptying and motility, caused by hypersplenism, increased intravascular hemolysis and increased levels of estrogen were the main reasons for the higher incidence of cholelithiasis in cirrhotic PHT patients (8).

Although cholecystectomy is the most effective practiced mode of therapy for symptomatic gallstones (9), not all patients are suitable for the surgical procedure. Cirrhosis and PHT are increasingly frequent conditions and are acknowledged to be associated with increased surgical risk after abdominal operations (10). Many investigators have observed that patients with cirrhosis and PHT tend to be more likely to have grave postoperative complications after cholecystectomy, frequently leading to their eventual death $(11,12)$. One study showed that open cholecystectomy for cirrhotic patients had an 11-fold risk of 30-day mortality compared to open cholecystectomy for noncirrhotic patients (13). Mortality after open cholecystectomy in cirrhotic patients varied between $0 \%$ and $7.7 \%(14,15)$. Most complications and deaths have been related to bleeding from the gallbladder bed, postoperative liver failure, and systemic infection. In addition, it has been suggested that changes in bile salt mechanisms that occur with the continuous secretion of bile into the gut after cholecystectomy may be associated with an increased risk of right-sided colonic cancer and other diseases (16). This continuous secretion leads to enhanced formation of secondary bile acids, such as lithocholic and deoxycholic acid, because of increased enterohepatic circulation and degradation of primary bile acids by intestinal bacteria. These secondary bile acids could act as cocarcinogens in adults. Subsequently, all these connections have led to some reservation in recommending cholecystectomy as a therapeutic procedure.

However, cholecystolithotomy carries the risk of residual or recurrent gallstones (17). In 100 patients who underwent successful percutaneous cholecystolithotomy for their gallstones, 3 to 50 months of follow-up revealed an overall stone recurrence rate of $31 \%$ and the cumulative proportion was $44 \%$ at 48 months
(18). So, controversy exists as to the optimal management of cholelithiasis and varies between cholecystostomy or cholecystectomy with stone removal and gallbladder preservation.

Our study found that no patients suffered from liver failure after cholecystolithotomy; nevertheless, occurrence of liver failure was found in $9.4 \%$ patients who underwent cholecystectomy. In the short-term follow-up course, comparison of hepatocyte functions and ChildPugh's classification revealed that there were less alterations in group A than in group B. Compared with cholecystectomy, cholecystolithotomy caused the patients less trauma and less operational stress, which was better for the maintenance of liver function. However, in the long-term follow-up course, the differences were not significant at 6 months postoperatively between the 2 groups; this may be due to the dominant influence of cirrhosis on liver function and cruor, with the influence of the operation diminishing gradually with time.

Increased portal pressure leads to splenomegaly, with consequent pooling and sequestration of corpuscular elements of the thrombocytes. Moreover, liver failure caused by cirrhosis reduces the hepatic synthesis of lineage-specific cytokine thrombopoietin, vitamin $\mathrm{K}$ and some coagulation factors. All of these can lead to coagulopathy and proneness to bleeding $(19,20)$. During the process of cholecystectomy, the gallbladder had to be separated from the liver and massive blood loss from the gallbladder bed was difficult to prevent. On the other hand, hyperdynamic splanchnic circulation of blood flow in the hepatic portal area is one of the remarkable features of PHT and a large number of collateral vessels and obvious varicose veins can be found around the gallbladder (21). Calot's triangle presented local fibrosis and edema and the gallbladder was embedded in the liver parenchyma. These factors caused more difficulty for the surgeon to dissect, and a proneness to vascular avulsion or hemorrhage. In cholecystolithotomy the risk of hemorrhage can be avoided, thereby diminishing the degree of operative difficulty. In such a situation, cholecystolithotomy is easier and 
probably safer than cholecystectomy. Our study showed that intraoperative blood loss of group A was less than group B; nevertheless, the devascularization accounted for the major part of intraoperative blood loss: blood loss in the surgical procedure related to the gallbladder was only about one fifth of the total which led to no significant difference between the two groups for total intraoperative blood loss.

Excluding the factor of intraoperative iatrogenic injury, biliary fistula was due to loose ligaturing in cystic duct stump and Luschka ducts or accessory hepatic duct injury. The edema and fibrillation of the cystic duct was very apparent in PHT patients, when the stump was ligated, the ligature was likely to fall off. Furthermore, a large number of lobular bile ducts (Luschka ducts) were disconnected around the gallbladder when the gallbladder was separated from liver and so biliary fistula was difficult to prevent. The edema and inflammation of Calot's triangle was the main risk factor for accessory hepatic duct injury during the process of cholecystectomy. Though biliary fistula might seal spontaneously, it will usually cause subphrenic infection and biliary peritonitis which can affect postoperative recovery. However, cholecystolithotomy reduced the risk factors for biliary fistula. In our study, the incidence of postoperative biliary fistula and subphrenic infection was much lower after cholecystolithotomy compared to cholecystectomy.

Some literature source have reported that cholecystolithotomy was associated with a high rate of recurrent gallstones, the recurrence often being preceded by sludge formation (22).

In our study, a flushing procedure was performed to avoid retention of muddy gallstones or biliary sludge after cholecystolithotomy. Armillarisin A is a coumarin derivative extracted from the fungus Armillariella tabescens (Scop. ex Fr.) (23). As an important component of traditional Chinese medicine, Armillarisin A is used as a choleretic to improve bile secretion and regulate the pressure of the bile duct in order to ease inflammation and prevent biliary sludge deposition. In the study, Armillarisin A was used both perioperatively and postoperatively. However, gallstone recurrence was found in only two patients of group A and the differences of incidence of recurrent gallstones in the two groups were not significant.

Cholecystolithotomy avoided the local dissection procedure especially in the gallbladder bed and Calot's triangle, thereby diminishing the degree of operative difficulty and reducing operation time. However, the flushing procedure may take a while for complete gallstone clearance (including muddy stones or biliary sludge). Therefore, the difference in mean operative time between the two groups was not significant.

After a mean follow-up of 4.2 years, all patients remain alive. Ninety-three percent of patients in group A are free of biliary symptoms, the rate being higher than that of group B. The difference, however, was not significant, so we would enlarge the object to continue the study.

\section{Conclusions}

Cholecystolithotomy combined with using Armillarisin A is an effective and safe treatment for symptomatic gallstones in patients with cirrhotic PHT who are at high risk for cholecystectomy. It preserves gallbladder function and reduces the possibility of liver failure; moreover the rate of recurrent gallstones is relatively low.

\section{Authors' contribution:}

Yang Fei, Guang-quan Zong wrote the paper, organized patient data; Jian Chen carried out the statistical analysis and corrected the paper; Wei-qin Li supervised the writing and organization process.

\section{Conflict of interest}

The authors declare that they have no competing interests. 


\section{References}

1. Bouchier IA. Postmortem study of the frequency of gallstones in patients with cirrhosis of the liver. Gut. 1969;10(9):705-10.

2. Csikesz NG, Tseng JF, Shah SA. Trends in surgical management for acute cholecystitis. Surgery. 2008;144(2):283-9.

3. de Goede B, Klitsie PJ, Lange JF, Metselaar HJ, Kazemier G. Morbidity and mortality related to non-hepatic surgery in patients with liver cirrhosis; a systematic review. Best Pract Res Clin Gastroenterol. 2012;26(1):47-59. doi: 10.1016/j.bpg.2012.01.010.

4. Zong GQ, Fei Y, Chen J, Liu RM. Selective double disconnection for cirrhotic portal hypertension. J Surg Res. 2014;192(2):383-9. doi: 10.1016/j.jss.2014.05.065. Epub 2014 May 27.

5. Ezzat FA, Abu-Elmagd KM, Aly MA, Fathy OM, el-Ghawlby NA, el-Fiky AM, et al. Selective shunt versus nonshunt surgery for management of both schistosomal and nonschistosomal variceal bleeders. Ann Surg. 1990;212(1):97-108.

6. Papatheodoridis GV, Goulis J, Leandro G, Patch D, Burroughs AK. Transjugular intrahepatic portosystemic shunt compared with endoscopic treatment for prevention of variceal rebleeding: a metaanalysis. Hepatology. 1999;30(3):612-22.

7. Conte D, Fraquelli M, Fornari F, Lodi L, Bodini P, Buscarini L. Close relation between cirrhosis and gallstones: cross-sectional and Iongitudinal survey. Arch Intern Med. 1999;159(1):49-52.

8. Schwesinger WH, Kurtin WE, Levine BA, Page CP. Cirrhosis and alcoholism as pathogenetic factors in pigment gallstone formation. Ann Surg. 1985;201(3):319-22.

9. McSherry CK. Cholecystectomy: the gold standard. Am J Surg. 1989;158(3):174-8.

10. Friedman LS. Surgery in the patient with liver disease. Trans Am Clin Climatol Assoc. 2010;121:192-204; discussion 205.

11. Metcalf AM, Dozois RR, Wolff BG, Beart RW Jr. The surgical risk of colectomy in patients with cirrhosis. Dis Colon Rectum. 1987; 30(7):529-31.

12. Garrison RN, Cryer HM, Howard DA, Polk HC Jr. Clarification of risk factors for abdominal operations in patients with hepatic cirrhosis. Ann Surg. 1984;199(6):648-55.

13. Thulstrup AM, Sørensen HT, Vilstrup H. Mortality after open chole- cystectomy in patients with cirrhosis of the liver: a populationbased study in Denmark. Eur J Surg. 2001;167(9):679-83.

14. El-Awadi S, El-Nakeeb A, Youssef T, Fikry A, Abd El-Hamed TM, Ghazy $\mathrm{H}$, et al. Laparoscopic versus open cholecystectomy in cirrhotic patients: a prospective randomized study. Int J Surg. 2009;7(1):66-9. doi: 10.1016/j.jijsu.2008.10.013. Epub 2008 Oct 26.

15. Hamad MA, Thabet M, Badawy A, Mourad F, Abdel-Salam M, AbdelRahman Mel-T, et al. Laparoscopic versus open cholecystectomy in patients with liver cirrhosis: a prospective, randomized study. J Laparoendosc Adv Surg Tech A. 2010;20(5):405-9. doi: 10.1089/ lap.2009.0476.

16. Friedman GD, Goldhaber MK, Quesenberry CP Jr. Cholecystectomy and large bowel cancer. Lancet. 1987;1(8538):906-8.

17. Gibney RG, Chow K, So CB, Rowley VA, Cooperberg PL, Burhenne HJ. Gallstone recurrence after cholecystolithotomy. AJR Am J Roentgenol. 1989;153(2):287-9.

18. Donald JJ, Cheslyn-Curtis S, Gillams AR, Russell RC, Lees WR. Percutaneous cholecystolithotomy: is gall stone recurrence inevitable? Gut. 1994;35(5):692-5.

19. Rios R, Sangro B, Herrero I, Quiroga J, Prieto J. The role of thrombopoietin in the thrombocytopenia of patients with liver cirrhosis. Am J Gastroenterol. 2005;100(6):1311-6.

20. Caldwell SH, Hoffman M, Lisman T, Macik BG, Northup PG, Reddy $\mathrm{KR}$, et al. Coagulation disorder and hemostasis in liver disease: pathophysiology and critical assessment of current management. Hepatology. 2006;44(4):1039-46.

21. Thabut D, Tazi KA, Bonnefont-Rousselot D, Aller M, Farges 0 , Guimont MC, et al. High-density lipoprotein administration attenuates liver proinflammatory response, restores liver endothelial nitric oxide synthase activity, and lowers portal pressure in cirrhotic rats. Hepatology. 2007;46(6):1893-906.

22. Petroni ML, Jazrawi RP, Pazzi P, Lanzini A, Zuin M, Pigozzi MG, et al.: Risk factors for the development of gallstone recurrence following medical dissolution. The British-Italian Gallstone Study Group. Eur J Gastroenterol Hepatol. 2000;12(6):695-700.

23. Wang Y, Wang YW, Li PF, Tang YB, Paul FJ, Gu JK. Quantitation of Armillarisin A in human plasma by liquid chromatography - electrospray tandem mass spectrometry. J Pharm Biomed Anal. 2007; 43(5):1860-3. Epub 2007 Jan 23 